\title{
The Impact of Ocean Acidification on the Functional Morphology of Foraminifera
}

\author{
Nikki Khanna ${ }^{1,3,5 *}$, Jasmin A. Godbold ${ }^{2}$, William E. N. Austin ${ }^{3,4}$, David M. Paterson ${ }^{1}$ \\ 1 Scottish Oceans Institute, School of Biology, University of St Andrews, St Andrews, Scotland, 2 Ocean and Earth Science, National Oceanography Centre, University of \\ Southampton, Southampton, United Kingdom, 3 School of Geography \& Geosciences, University of St Andrews, St Andrews, Scotland, 4 Scottish Association for Marine \\ Science, Scottish Marine Institute, Oban, Scotland, 5 Ichron Limited, Northwich, United Kingdom
}

\begin{abstract}
Culturing experiments were performed on sediment samples from the Ythan Estuary, N. E. Scotland, to assess the impacts of ocean acidification on test surface ornamentation in the benthic foraminifer Haynesina germanica. Specimens were cultured for 36 weeks at either 380,750 or 1000 ppm atmospheric $\mathrm{CO}_{2}$. Analysis of the test surface using SEM imaging reveals sensitivity of functionally important ornamentation associated with feeding to changing seawater $\mathrm{CO}_{2}$ levels. Specimens incubated at high $\mathrm{CO}_{2}$ levels displayed evidence of shell dissolution, a significant reduction and deformation of ornamentation. It is clear that these calcifying organisms are likely to be vulnerable to ocean acidification. A reduction in functionally important ornamentation could lead to a reduction in feeding efficiency with consequent impacts on this organism's survival and fitness.
\end{abstract}

Citation: Khanna N, Godbold JA, Austin WEN, Paterson DM (2013) The Impact of Ocean Acidification on the Functional Morphology of Foraminifera. PLoS ONE 8(12): e83118. doi:10.1371/journal.pone.0083118

Editor: Lee A. Newsom, The Pennsylvania State University, United States of America

Received June 17, 2013; Accepted October 30, 2013; Published December 17, 2013

Copyright: (c) 2013 Khanna et al. This is an open-access article distributed under the terms of the Creative Commons Attribution License, which permits unrestricted use, distribution, and reproduction in any medium, provided the original author and source are credited.

Funding: This work was supported by the NERC UK Ocean Acidification Research Programme grant NE/H017445/1. WENA acknowledges NERC support (NE/ G018502/1). DMP received funding from the MASTS pooling initiative (The Marine Alliance for Science and Technology for Scotland). MASTS is funded by the Scottish Funding Council (grant reference HR09011) and contributing institutions. The funders had no role in study design, data collection and analysis, decision to publish, or preparation of the manuscript.

Competing Interests: The authors have declared that no competing interests exist.

*E-mail: nk274@st-andrews.ac.uk

\section{Introduction}

Elevated atmospheric concentrations of carbon dioxide $\left(\mathrm{CO}_{2}\right)$, primarily driven by anthropogenic activity, are driving down the $\mathrm{pH}$ of the oceans [1]. It is estimated that the oceans have absorbed half of the total anthropogenic $\mathrm{CO}_{2}$ produced in the last 200 years, reducing oceanic $\mathrm{pH}$ by 0.1 units [1] and simultaneously affecting the carbonate ion concentration [2]. A further decrease of $0.3-$ $0.5 \mathrm{pH}$ units is predicted by 2100 [3]. One of the most significant implications is the likely reduction in calcifying capacity of marine organisms $[4,5]$. The experimental responses of organisms that produce carbonate structures have however been variable depending on the type and length of exposure $[6,7]$.

Foraminifera are amoeboid protozoa that constitute one the most widespread and diverse groups of shelled microorganisms in the modern oceans. They occur in planktic and benthic habitats from the intertidal coastal habitats to the deep sea [8]. The majority of benthic foraminifera build their tests (shells) with calcium carbonate $\left(\mathrm{CaCO}_{3}\right)$ [9] playing an important role in the carbon cycle of intertidal estuarine sediments [10].

The evolutionary and ecological success of shelled foraminifera depends on the functional significance of the test $[11,12]$. The test provides shelter and protection from predators, assistance in cell growth, aids in reproduction, acts as a receptacle for excreted matter, and provides buoyancy control [13-15]. There are also morphological features and ornamentation on the test that are of functional importance. For example, tubercles and teeth in the apertures (Fig. 1) of some species are important in feeding and serve to break up aggregates of food and detritus [16]. Tubercles are protrusions that border the chamber margins while teeth are similar protrusions that are found adjacent to the aperture, occupying part of the apertural space [17]. Hamm et al. [18] speculated that diatom grazers are likely to have evolved specialised tools to break open frustules. Austin et al. [12] documented extracellular cracking and removal of diatom contents, aided by the presence of 'tooth-like' dentition in Haynesina germanica (Ehrenberg).

To date, researchers have examined ocean acidification impacts on benthic foraminifera via test weight, thickness and growth rate [19-21]. However, there is currently no information on how foraminiferal test functional morphology might respond to ocean acidification.

Here we present ultrastructural observations using scanning electron microscopy of cultured $H$. germanica to examine the effect of different levels of atmospheric $\mathrm{CO}_{2}$ on test morphology, focussing on the apertural region known to have functional ornamentation [12].

\section{Materials and Methods}

Sediment was collected from the Ythan Estuary, N.E. Scotland $\left(57^{\circ} 20^{\prime} \mathrm{N}, 01^{\circ} 57^{\prime} \mathrm{W}\right)$, in December 2010 . No specific permissions were required for sediment sampling at this location and the sampling did not involve endangered or protected species. Sieved sediment $(500 \mu \mathrm{m})$, was added to acrylic mesocosms $(12 \times 12 \times 33 \mathrm{~cm})$ to a depth of $12 \mathrm{~cm}$ and $20 \mathrm{~cm}$ of overlying seawater. Mesocosms were exposed to a seasonally varying light cycle and maintained at $10^{\circ} \mathrm{C}$ (average local conditions). Seawater 

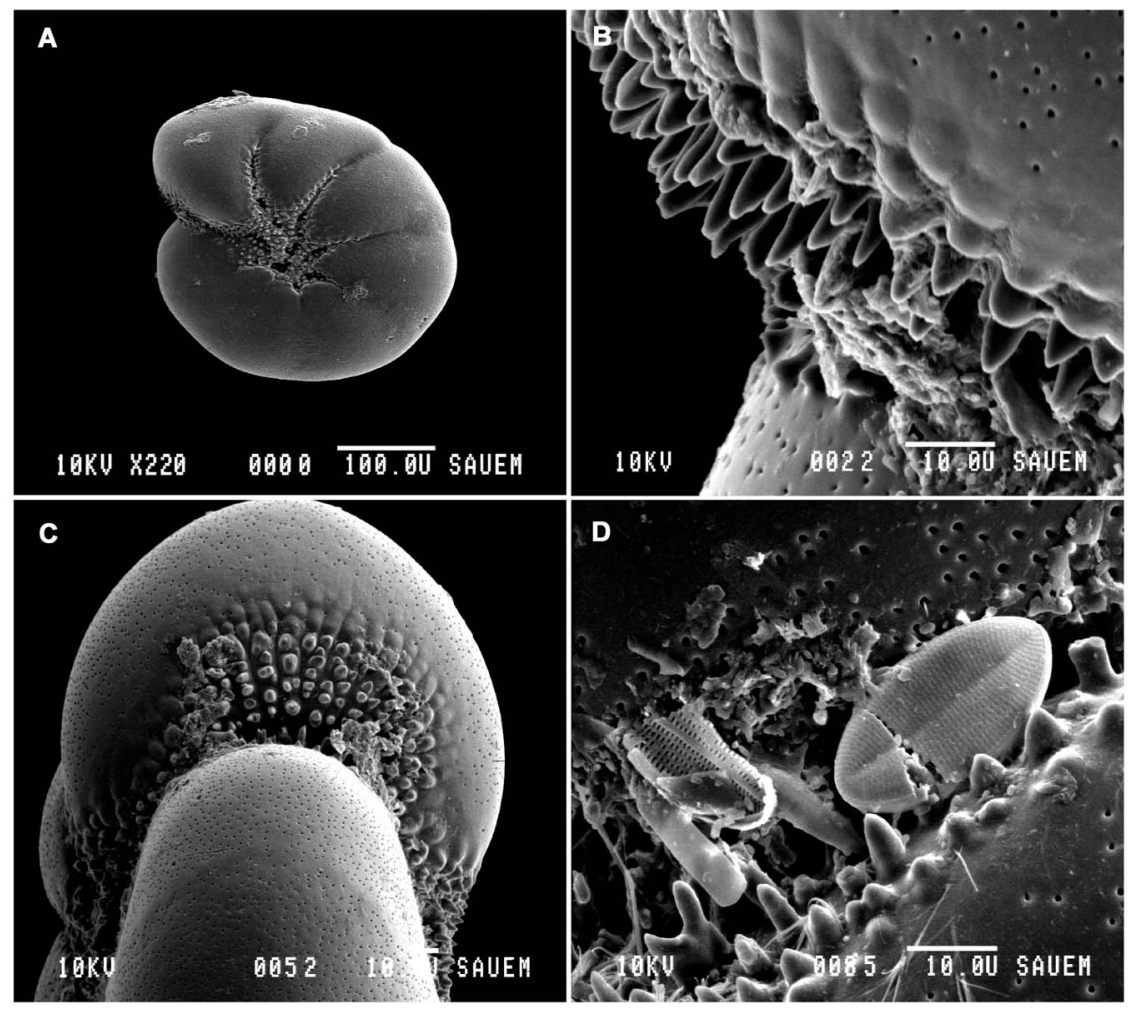

Figure 1. Scanning electron micrographs of Haynesina germanica. (A) Scanning electron micrograph of typical test, side view. (B) Higher magnification view of apertural region, showing tubercles and teeth lining the aperture. (C) Scanning electron micrograph of typical test, apertural view. (D) Higher magnification view of apertural region. Note impaled diatom $\left(^{*}\right)$.

doi:10.1371/journal.pone.0083118.g001

$\mathrm{pH}$ was controlled by bubbling air with a known concentration of $\mathrm{CO}_{2}(380,750,1000 \mathrm{ppm})$ into each mesocosm [22]. Seawater $\mathrm{pH}$, temperature and salinity were monitored weekly and atmospheric $\mathrm{CO}_{2}$ was maintained at 380 , 750 or $1000 \mathrm{ppm}$ (Table S1). After 36 weeks of exposure, surface scrapes of 1-2 mm depth were collected from each of the treatments for the isolation of living benthic foraminifera.

The surface scrapes were fixed in ethanol and stained with rose Bengal (to distinguish live individuals). After $24 \mathrm{~h}$, samples were washed over a $63 \mu \mathrm{m}$ sieve and the coarse fraction dried $\left(<40^{\circ} \mathrm{C}\right)$. 15 live adult specimens of Haynesina germanica $(300-400 \mu \mathrm{m})$, five from each $\mathrm{CO}_{2}$ treatment, were selected using a fine paintbrush under an Olympus ${ }^{\circledR} \mathrm{SZ}$ stereo-microscope and dry-stored on micropalaeontological slides prior to imaging with a scanning electron microscope (SEM). The foraminiferal specimens were mounted onto SEM stubs using double-sided adhesive tabs. Samples were prepared with an Emscope ${ }^{\circledR}$ SC 500 sputter coater and imaged with a scanning electronic microscope (Joel ${ }^{\circledR}$ JSM$35 \mathrm{CF}$ SEM). For each specimen, the number of teeth in a $20 \mu \mathrm{m}^{2}$ region of the apertural area were counted and measured (SemAfore ${ }^{\circledR}$ ) for maximum length and width (Table 1). Once assumptions were confirmed, a one-way ANOVA was used to determine the effects of $\mathrm{CO}_{2}$. Analyses were performed using the statistical programming software ' $\mathrm{R}$ ' [23].

\section{Results}

SEM imaging of Haynesina germanica revealed differences between specimens cultured in each of the $\mathrm{CO}_{2}$ treatments. There was a statistically significant difference in the average number $(\mathrm{df}=2, \mathrm{~F}=9.8369, \mathrm{p}<0.05)$, length $(\mathrm{df}=2, \mathrm{~F}=9.6467$, $\mathrm{p}<0.0001)$ and width $(\mathrm{df}=2, \mathrm{~F}=4.0073, \mathrm{p}<0.05)$ of teeth.

. 2A). Several specimens also had diatoms impaled on teeth close to the apertural region. In addition, the test surface was smooth and unblemished (Fig. 2B).

At $750 \mathrm{ppm}$, specimens displayed similar shell appearance to those observed at $380 \mathrm{ppm}$ (Fig. 2C). The teeth were of a similar size and shape but in many cases there was a reduction in overall number $(10.80 \pm 3.96)$ in comparison to the control $(15.20 \pm 2.49)$. The test surfaces also appeared smooth although some signs of cracking were evident (Fig. 2D).

At the highest $\mathrm{CO}_{2}$ treatment (1000 ppm), there were marked signs of dissolution and deformation features on multiple individuals in comparison to those cultured at 380 and 750 ppm. Dissolution was evident on the test surface (Fig. 2E, F) and in many cases the teeth were completely absent (Fig. 2E). In those specimens from the high $\mathrm{CO}_{2}$ treatment that retained some ornamentation, the shape and appearance was highly irregular. Teeth were less conical and more rounded in shape. In addition, the entire test surface appeared to be partially dissolved with evidence of cracking (Fig. 2F), which was entirely absent from control specimens.

\section{Discussion}

Measurement data demonstrate that test ornamentation of functional importance for Haynesina germanica is sensitive to decreasing seawater $\mathrm{pH}$. Under ambient conditions, the test surface of $H$. germanica is smooth with the primary openings along the base of the apertural face being obscured externally by teeth that are usually conical in shape. Foraminifera maintained at 
Table 1. Summary of main morphological features at each $\mathrm{CO}_{2}$ treatment.

\begin{tabular}{|c|c|c|c|c|c|c|}
\hline $\begin{array}{l}\mathrm{CO}_{2} \text { Treatment } \\
(\mathrm{ppm})\end{array}$ & $\begin{array}{l}\text { average number of } \\
\text { "teeth" (mean } \pm S D)\end{array}$ & $\begin{array}{l}\text { average length of } \\
\text { "teeth" (mean } \pm S D)\end{array}$ & $\begin{array}{l}\text { average width of } \\
\text { "teeth" (mean } \pm S D)\end{array}$ & $\begin{array}{l}\text { observational } \\
\text { notes on "teeth" }\end{array}$ & $\begin{array}{l}\text { test surface } \\
\text { observations }\end{array}$ & $\begin{array}{l}\text { number of diatom } \\
\text { frustules in } \\
\text { apertural region }\end{array}$ \\
\hline 380 & $15.20 \pm 2.49(n=76)$ & $6.53 \pm 2.13$ & $3.27 \pm 1.00$ & $\begin{array}{l}\text { Teeth predominantly } \\
\text { conical in shape }\end{array}$ & $\begin{array}{l}\text { Test surfaces smooth } \\
\text { with little evidence of } \\
\text { dissolution }\end{array}$ & 7 \\
\hline 750 & $10.80 \pm 3.96(n=54)$ & $5.26 \pm 1.79$ & $3.27 \pm 1.16$ & $\begin{array}{l}\text { Teeth conical in shape. } \\
\text { A number of broken } \\
\text { teeth also observed. }\end{array}$ & $\begin{array}{l}\text { Some small areas of } \\
\text { dissolution and pitting } \\
\text { evident. }\end{array}$ & 2 \\
\hline 1000 & $6.60 \pm 2.51(n=33)$ & $5.01 \pm 1.94$ & $3.99 \pm 1.97$ & $\begin{array}{l}\text { Teeth tended to be } \\
\text { fewer and generally } \\
\text { more rounded in shape. } \\
\text { Of those counted } \\
\text { a number were broken } \\
\text { or deformed. }\end{array}$ & $\begin{array}{l}\text { Dissolved patches more } \\
\text { extensive and numerous } \\
\text { in addition to visible } \\
\text { cracking }\end{array}$ & 0 \\
\hline
\end{tabular}

ambient $\mathrm{CO}_{2}$ levels had tubercles and teeth that were numerous and very well developed in both the apertural and umbilical regions. At higher $\mathrm{CO}_{2}$ levels the functional ornamentation of the apertural area was vastly reduced and the extent to which these apertural and umbilical features were dissolved or damaged makes the foraminifera almost unrecognizable as $H$. germanica (Fig. 2).

One of the keys to evolutionary success of foraminifera are the finely tuned relationships they have developed to exploit the food resources of their community [24]. Bernard and Bowser [16] document the significance of foraminiferal test functional morphology in species known to sequester chloroplasts, and showed that the external test ornamentations facilitate separation of chloroplasts from algal prey. As particles are moved past the tubercles, they are sorted by size, where larger fragments become disaggregated in preparation for later ingestion. Austin et al. [12]
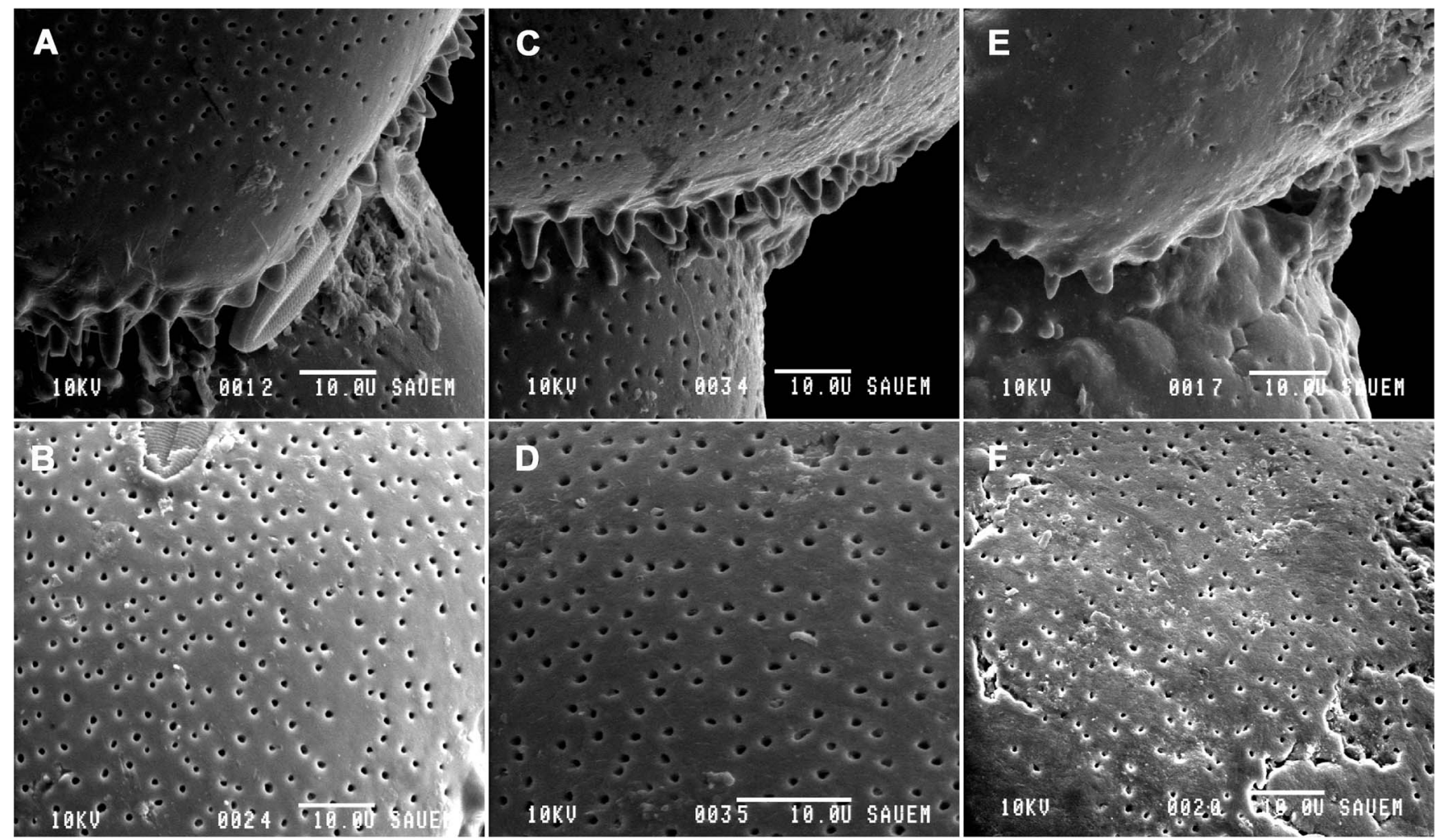

Figure 2. Scanning electron micrographs of Haynesina germanica following exposure to each of the $\mathrm{CO}_{2}$ treatments. SEM images of specimens taken at $380 \mathrm{ppm}(\mathrm{A} \& \mathrm{~B}), 750 \mathrm{ppm}(\mathrm{C} \& \mathrm{D})$ and $1000 \mathrm{ppm}(\mathrm{E} \& \mathrm{~F})$. (A) Side view of apertural region showing numerous sharp tubercles. Note diatom impaled on ornamentation $\left(^{*}\right)$. (B) Scanning electron micrograph of test surface of specimen 2A. (C) Side view of apertural region, showing tubercles and teeth. (D) Scanning electron micrograph of test surface of specimen 2C. (E) Side view of apertural region. Note the distinct absence of the numerous conical tubercles present in 2A. (F) Scanning electron micrograph of test surface of specimen 2E. Note surface dissolution and cracking damage.

doi:10.1371/journal.pone.0083118.g002 
showed a direct relationship between fracturing in diatoms and feeding sequestration by $H$. germanica.

Test ornamentation, notably around the apertural area, is therefore crucial for feeding and chloroplast acquisition in $H$. germanica. Dissolution of these features at anticipated future levels of atmospheric $\mathrm{CO}_{2}$ will therefore have a direct negative impact on the long-term fitness and survival on these organisms through a reduction in feeding efficiency.

The potential for deformation, dissolution and in some cases absence of these functionally important feeding structures, may result in a shift in competitive advantage towards non-calcifiers in the benthic foraminiferal community under conditions of enhanced ocean acidification. This shift in community structure is likely to be further enhanced as a result of weakened tests under high- $\mathrm{CO}_{2}$ scenarios, making calcifying foraminifera such as $H$. germanica more vulnerable to predators. Such shifts in community structure will have significant knock-on effects for trophic dynamics, carbon cycling and ecosystem productivity.

\section{References}

1. Hoegh-Guldberg O, Bruno JF (2010) The impact of climate change on the world's marine ecosystems. Science 328: 1523-1528.

2. Orr JC, Fabry VJ, Aumont O, Bopp L, Doney SC, et al (2005) Anthropogenic ocean acidification over the twenty-first century and its impact on calcifying organisms. Nature 437: 681-686.

3. Caldeira K, Wickett ME (2003) Anthropogenic carbon and ocean pH. Nature 425. 325 .

4. Doney SC, Fabry VJ, Feely RA, Kleypas JA (2009) Ocean acidification: the other $\mathrm{CO}_{2}$ problem. Ann Rev Mar Sci 1: 169-192.

5. Kroeker KJ, Kordas RL, Crim RN, Singh GG (2010) Meta-analysis reveals negative yet variable effects of ocean acidification on marine organisms. Ecol Lett 13: 1419-1434.

6. Gooding RA, Harley CDG, Tang E, Brown JH (2009) Elevated water temperature and carbon dioxide concentration increase growth of a keystone echinoderm. PNAS 106: 9316-9321.

7. Form AU, Reibesell U (2012) Acclimation to ocean acidification during long term $\mathrm{CO}_{2}$ exposure in the cold water coral Lophelia pertusa. Glob Change Biol 18: $843-853$.

8. Goldstein ST (1999) Foraminifera: A Biological Overview. In: Sen Gupta BK. Modern Foraminifera. Dordrecht: Kluwer Academic Publishers. pp. 37-55.

9. Hansen HJ (1999) Shell construction in modern calcareous Foraminifera. In: Sen Gupta BK. Modern Foraminifera. Dordrecht: Kluwer Academic Publishers. pp. $57-70$.

10. Moodley L, Boschker HTS, Middelburg JJ, Pel R, Hermna PMJ, et al. (2000) Ecological significance of benthic foraminifera: ${ }^{13} \mathrm{C}$ labelling experiments. Mar Ecol Prog Ser 202: 289-295.

11. Murray JW (2006) Ecology and Applications of Benthic Foraminifera. Cambridge: Cambridge University Press.

12. Austin HA, Austin WEN, Paterson DM (2005) Extracellular cracking and content removal of the benthic diatom Pleurosigma angulatum (Quekett) by the benthic foraminifera Haynesina germanica (Ehrenberg). Mar Micropal 57: 68-73.

13. Marszalek DS, Wright RC, Hay WW (1969). Function of the test in foraminifera. Trans Gulf Coast Assoc Geol Soc 19: 341-352.

\section{Supporting Information}

Table S1 Seawater measurements from experimental mesocosms. The measured values of temperature, salinity and $\mathrm{pH}$ (NBS scale) and total alkalinity $\left(\mathrm{A}_{\mathrm{T}}\right)$ were used to calculate the values of dissolved inorganic carbon (DIC), $\mathrm{pCO}_{2}$, saturation states of calcite $\left(\Omega_{\text {calcite }}\right)$ and aragonite $\left(\Omega_{\text {aragonite }}\right)$, bicarbonate $\left(\mathrm{HCO}_{3}\right)$ and carbonate concentration $\left(\mathrm{CO}_{3}{ }^{2-}\right)$ using $\mathrm{CO}_{2}$ Calc. (PDF)

\section{Acknowledgments}

This study forms part of NK's PhD study. NK would like to thank I. Davidson for laboratory and SEM support.

\section{Author Contributions}

Conceived and designed the experiments: NK JAG DP. Performed the experiments: NK JAG. Analyzed the data: NK JAG DP WENA. Contributed reagents/materials/analysis tools: NK JAG. Wrote the paper: NK JAG WENA DP.

14. Murray JW (1991) Ecology and Palaeoecology of Benthic Foraminifera. Harlow: Longman.

15. Hallock P, Röttger R, Wetmore K (1991) Hypotheses on form and function in foraminifera. In: Lee JJ, Anderson OR. Biology of Foraminifera. London: Academic. pp. 41-72.

16. Bernhard JM, Bowser SS (1999) Benthic foraminifera of dysoxic sediments: chloroplast sequestration and functional morphology. Earth Sci Rev 46: 149165.

17. Loeblich AR, Tappan H (1988) Foraminiferal Genera and their Classification. New York: Van Nostrand Reinhold.

18. Hamm CE, Merkel R, Springer O, Jurkojc P, Maler C, et al. (2003) Architecture and material properties of diatom shells provided effective mechanical protection. Nature 421: 841-843.

19. Le Cadre V, Debanay JP, Lesourd M (2003) Low pH effects on Ammonia beccarii test deformation: implications for using test deformations as a pollution indicator. J Foraminiferal Res 33: 1-9.

20. Dissard D, Nehrke G, Reichart GJ, Bijma J (2009) Impact of seawater $\mathrm{pCO}_{2}$ changes on calcification and on $\mathrm{Mg} / \mathrm{Ca}$ and $\mathrm{Sr} / \mathrm{Ca}$ in benthic foraminifera calcite (Ammonia tepida): results from culturing experiments. Biogeosciences 7: 8193

21. Haynert K, Schönfeld J, Riebesell U, Polovodova I (2011) Biometry and dissolution features of the benthic foraminifer Ammonia aomoriensis at high $\mathrm{pCO}_{2}$. Mar Ecol Prog Ser 432: 53-67.

22. Godbold JA, Solan M (2013) Long-term effects of warming and ocean acidification are modified by seasonal variation in species responses and environmental conditions. Phil Trans R Soc Lond B 368:20130186

23. R Development Core Team (2012) R: a language and environment for statistical computing. Vienna, Austria. See http://www.R-project.org/.

24. Lee JJ (1980) Nutrition and Physiology of the Foraminifera. In: Levandowsky ML, Hunter SH. Biogeochemistry and Physiology of Protozoa. London: Academic Press. pp. 43-66. 